\title{
ANALISIS HASIL BELAJAR MATEMATIKA DITINJAU DARI KECERDASAN EMOSIONAL PESERTA DIDIK KELAS V SDN 204 PALEMBANG
}

\author{
Feniareny DA \\ SD Negeri 199 Palembang \\ feniareny@gmail.com
}

\begin{abstract}
ABSTRAK
Penelitian ini bertujuan untuk mengetahui dan mendeskripsikan hasil belajar matematika peserta didik kelas V SD Negeri 204 Palembang ditinjau dari kecerdasan emosionalnya. Penelitian ini merupakan penelitian deskriptif. Subjek dalam penelitian ini berjumlah 74 orang. Proses pengumpulan data dengan menggunakan angket dan tes. Analisis data menggunakan model Miles dan Hubermann. Data tingkat kecerdasan emosional siswa diperoleh dengan kriteria sangat baik 12 orang $(16,2 \%)$, kriteria baik 34 orang $(45,9 \%)$, cukup baik 15 orang $(20,3 \%)$, dan kurang baik 13 orang $(17,6 \%)$. Hasil belajar peserta didik diperoleh dengan kriteria sangat baik ada 12 orang $(16,2 \%)$, kriteria baik ada 36 orang $(48,6 \%)$, cukup baik 16 orang (35\%), kurang baik 5 orang $(6,8 \%)$, dan tidak baik 5 orang $(6,8 \%)$. Sehingga disimpulkan ada hubungan yang positif antara kecerdasan emosional dengan hasil belajar.
\end{abstract}

Kata kunci : kecerdasan emosional, hasil belajar

\begin{abstract}
This study aims to determine and describe the mathematics learning outcomes of grade V SD Negeri 204 Palembang in terms of their emotional intelligence. This research is descriptive. The subjects in this study were 74 people. Data were collected through questionnaires and tests. Miles and Hubermann's model have been used for data processing. Emotional intelligence results were obtained with very strong parameters in terms of 12 persons $(16,2 \%), 34$ persons $(45,9 \%)$, adequate for 15 persons $(20,3 \%)$ and poorly for 13 persons (17,6 percent). Student learning outcomes were obtained with very good criteria, there were 12 people $(16,2 \%)$, good criteria were 36 people $(48,6 \%)$, good enough 16 people (35\%), less good 5 people $(6,8 \%)$, and not good 5 people $(6,8 \%)$. So it can be concluded that there is a positive relationship between emotional intelligence and learning outcomes.
\end{abstract}

Keywords : emotional intelligence, learning outcomes

\section{PENDAHULUAN}

Pendidikan adalah suatu usaha atau kegiatan yang dijalankan dengan sengaja, teratur dan berencana dengan maksud mengubah atau mengembangkan perilaku yang diinginkan. Sekolah merupakan lembaga pendidikan yang berfungsi sebagai sarana peserta didik belajar. Pendidikan formal, dalam belajar menunjukkan adanya perubahan yang sifatnya positif sehingga pada tahap akhir akan didapat 
keterampilan, kecakapan dan pengetahuan baru. Hasil dari proses belajar tersebut tercermin dalam hasil belajarnya.

Pertama, belajar merupakan suatu kegiatan yang dilakukan sehari-hari bagi peserta didik di sekolah. Melalui proses belajar tersebut diharapkan timbul perubahan tingkah laku pada peserta didik. Perubahan tingkah laku dapat mencakup aspek pengetahuan, keterampilan, nilai, dan sikap. Hal ini diperkuat oleh Slameto (2016) bahwa belajar adalah suatu proses usaha yang dilakukan seseorang untuk memperoleh suatu perubahan tingkah laku yang baru secara keseluruhan, sebagai hasil pengalamannya sendiri dalam interaksi dengan lingkungannya. Perubahan tingkah laku tersebut mencakup perubahan pengetahuan, pemahaman, keterampilan, dan sikap dari seseorang yang mengalami proses belajar

Kedua, mengajar merupakan kegiatan dimana guru berusaha untuk membuat peserta didik menguasai pengetahuan yang disampaikan dengan menggunakan bermacam-macam model, strategi, metode, dan pendekatan. Dalam mengajar guru harus membimbing aktivitas peserta didik agar mereka menemukan sendiri pengetahunnya. Guru berperan sebagai fasilitator yang mengatur lingkungan pembelajaran. Hal ini sesuai dengan pend apat yang dikemukakan Nasution (1995: 4) bahwa mengajar adalah suatu aktivitas yang mengorganisasi atau mengatur lingkungan sebaik-baiknya dan menghubungkannya dengan anak sehingga terjadi proses belajar. Proses pengaturan yang dilakukan guru bertujuan agar terjadi interaksi antara peserta didik dengan guru, sesama peserta didik, dan lingkungan dengan sumber belajar.

Namun dalam upaya meraih hasil belajar dipengaruhi faktor internal salah satunya adalah Emotional Intelligence atau kecerdasan emosional (EQ). Para ahli berpendapat bahwa untuk meraih hasil belajar yang optimal, seseorang tidak hanya memiliki Intelligence Quotient (IQ) yang tinggi, IQ bukan merupakan satu-satunya faktor yang menentukan keberhasilan seseorang, karena ada faktor lain yang mempengaruhi hasil belajar. IQ tidak dapat berfungsi dengan baik tanpa partisipasi penghayatan emosional terhadap mata pelajaran yang disampaikan di sekolah. Pendidikan di sekolah tidak hanya mengembangkan IQ saja melainkan juga perlu mengembangkan kecerdasan emosional peserta didik. Kedua kecerdasan itu saling melengkapi. Keseimbangan antara IQ dan EQ merupakan kunci keberhasilan belajar peserta didik di sekolah.

Kecerdasan emosional peserta didik memiliki pengaruh terhadap hasil belajar peserta didik. Kecerdasan emosional ini mampu melatih kemampuan untuk mengelola perasaannya, kemampuan untuk memotivasi dirinya, kesanggupan untuk tegar dalam menghadapi frustasi, kesanggupan mengendalikan dorongan dan menunda kepuasan sesaat, mengatur suasana hati yang reaktif, serta mampu berempati dan bekerja sama dengan orang lain. Kecerdasan ini yang mendukung seorang peserta didik dalam mencapai tujuan dan cita-citanya. Tak sedikit orang gagal dalam hidupnya bukan karena kecerdasan intelektualnya rendah, namun karena mereka kurang memiliki kecerdasan emosional. Tidak sedikit orang yang sukses dalam hidupnya karena memiliki kecerdasan emosional, meskipun inteligensi intelektualnya hanya pada tingkat rata-rata (Yusuf, 2002:239).

Dalam pembelajaran yang menggunakan pendekatan emosional, perhatian akan perkembangan intelektual anak dianggap penting, hal ini sejalan dengan pandangan Semiawan (dalam Uno, 2008:115) bahwa stimulasi intelektual sangat dipengaruhi keterlibatan emosional, bahkan emosional juga amat menentukan perkembangan 
intelektual anak secara bertahap, artinya secara timbal-balik faktor kognitif juga terlibat dalam perkembangan emosional. Dengan demikian, antara EQ dengan IQ tidak dapat dipisahkan perannya satu sama lain. Keberadaan EQ sangat menunjang berfungsinya IQ begitupun sebaliknya, atau dapat dikatakan antara IQ dan EQ ibarat dua sisi mata uang dalam satu keping logam (Uno, 2008:116).

Akan tetapi dunia pendidikan sekarang ini, terlalu menekankan pentingnya nilai akademik saja. Padahal yang diperlukan bagaimana mengembangkan kecerdasan emosional seperti ketangguhan, inisiatif, optimis, dan kemampuan beradaptasi. Peserta didik saat ini lebih sering mengalami masalah emosi seperti tumbuh dalam kesepian dan depresi, mudah marah, lebih sulit diatur, lebih gugup dan cenderung cemas, impulsif dan agresif (Agustian, 2007: 6). Dengan sentuhan dan pendekatan Emotional Intelligence membuat seseorang mampu membuka diri untuk membangkitkan potensinya yang selama ini terpendam dan meraih hasil belajar terbaik (Fuad, 2004: 5).

Kenyataannya, dalam proses belajar-mengajar di sekolah sering ditemukan peserta didik yang tidak dapat meraih hasil belajar yang setara dengan kemampuan inteligensinya. Ada peserta didik yang mempunyai kemampuan inteligensi tinggi tetapi memperoleh hasil belajar yang relatif rendah, namun ada peserta didik yang walaupun kemampuan inteligensinya relatif rendah, dapat meraih hasil belajar yang relatif tinggi. Itu sebabnya taraf inteligensi bukan merupakan satu-satunya faktor yang menentukan keberhasilan seseorang, karena ada faktor lain yang mempengaruhi.

Dalam proses belajar peserta didik, kedua inteligensi itu sangat diperlukan. IQ tidak dapat berfungsi dengan baik tanpa partisipasi penghayatan emosional terhadap mata pelajaran yang disampaikan di sekolah. Namun biasanya kedua inteligensi itu saling melengkapi. Keseimbangan antara IQ dan EQ merupakan kunci keberhasilan belajar peserta didik di sekolah (Goleman, 2016 :65). Pendidikan di sekolah bukan hanya perlu mengembangkan rational intelligence yaitu model pemahaman yang lazimnya dipahami peserta didik saja, melainkan juga perlu mengembangkan emotional intelligence peserta didik.

Menurut Goleman (2016: 44), kecerdasan intelektual (IQ) hanya menyumbang $20 \%$ bagi kesuksesan, sedangkan $80 \%$ adalah sumbangan faktor kekuatan-kekuatan lain, diantaranya adalah kecerdasan emosional atau Emotional Quotient (EQ) yakni kemampuan memotivasi diri sendiri, mengatasi frustasi, mengontrol desakan hati, mengatur suasana hati (mood), berempati serta kemampuan bekerja sama.

Senada juga menurut Ilyas (2014: 47), bahwa rendahnya prestasi belajar matematika peserta didik tidak terlepas dari faktor internal dan eksternal. Faktor internal banyak didominasi oleh kondisi psikologis dan berbagai potensi peserta didik dalam bentuk kecerdasan, termasuk intelegensi atau kecerdasan intelektual yang meliputi berbagai kemampuan, seperti kemampuan numerik, kemampuan keruangan, kemampuan penalaran, kemampuan berpikir abstrak, dan kemampuan verbal. Demikian juga kecerdasan emosional (Emotional Intelligence) yang meliputi ketabahan, keterampilan bergaul, empati, kesabaran, kesungguhan, keuletan, ketangguhan, kepercayaan pada diri sendiri, dan sebagainya. Faktor eksternal beraneka ragam, misalnya faktor lingkungan, baik lingkungan keluarga, maupun lingkungan kampus dan masyarakat.

Kecerdasan emosional adalah kemampuan seseorang mengatur kehidupan emosinya dengan inteligensi (to manage our emotional life with intelligence); 
menjaga keselarasan emosi dan pengungkapannya (the appropriateness of emotion and its expression) melalui keterampilan kesadaran diri, pengendalian diri, motivasi diri, empati dan keterampilan sosial (Goleman, 2016 : 512). Menurut Goleman (2016) khusus pada orang-orang yang murni hanya memiliki kecerdasan akademis tinggi, mereka cenderung memiliki rasa gelisah yang tidak beralasan, terlalu krit is, rewel, cenderung menarik diri, terkesan dingin dan cenderung sulit mengekspresikan kekesalan dan kemarahannya secara tepat.

Khusus untuk anak SD, kecerdasan emosional mereka belum stabil dan masih berkembang mengikuti pertumbuhan usia. Kecerdasan emosi anak SD lebih cenderung tidak dapat diprediksi karena sikap anak masih berubah-ubah. Tahap perkembangan emosi anak juga dipengaruhi oleh faktor yang terkait dengan lingkungannya. Perkembangan emosi anak usia SD banyak berada di lingkungan sekolah. Mereka belajar bagaimana cara beradaptasi dengan teman sebaya, lingkungan sekolah, tenaga didik baru, termasuk juga suasana kelas baru. Mereka mulai mengembangkan keterampilan sosial, seperti bagaimana mematuhi aturanaturan yang berkaitan dengan pergaulan, belajar mengenai bermain dengan aturan dan tahapan tertentu. Belajar mengenai mata pelajaran di sekolah, serta mampu mempersiapkan diri untuk memahami materi pada mata pelajaran tersebut.

Tujuan penelitian ini adalah untuk mengetahui dan mendeskripsikan hasil belajar matematika peserta didik kelas V SD Negeri 204 Palembang ditinjau dari kecerdasan emosionalnya.

\section{METODE}

Jenis Penelitian ini merupakan penelitian deskriptif. Dalam penelitian ini yang menjadi subjek adalah semua peserta didik kelas V SD Negeri 204 Palembang Tahun Ajaran 2017/2018 yang berjumlah 74 peserta didik. Proses pengumpulan data, yaitu menggunakan angket dan tes.

Angket yang disebarkan terdiri dari 25 butir pernyataan, dengan alternatif jawaban menggunakan skala likert yaitu selalu, sering, kadang-kadang, pernah, tidak pernah. Pernyataan yang dibuat berdasarkan 5 indikator yaitu mengenali emosi diri, mengelola emosi, memotivasi diri sendiri, mengenali emosi orang lain, dan membina hubungan.

Teknik analisis dan pengolahan data digunakan model yang dirancang oleh Miles dan Hubermann (Sugiyono, 2008: 91) yakni analisis dan pengumpulan data kualitatif memperlihatkan sifat interaktif, seperti sebuah sistem dan menunjukkan suatu siklus. Teknik analisis datanya yaitu reduksi data, display data serta kesimpulan dan verifikasi.

Reduksi data dan penyajian hasilnya dilakukan secara terus-menerus selama pengumpulan data berlangsung. Jika pada sajian dirasakan masih terdapat kejanggalan-kejanggalan, maka segera diadakan reduksi melalui verifikasi data dengan data yang lain untuk mencari data baru (Sugiyono, 2014).

Tahap pemaparan atau penyajian data. Teknik penyajian data yang digunakan dalam penelitian ini adalah deskripsi kata-kata yang bersifat naratif. Pemaparan data akan memudahkan untuk memahami apa yang terjadi, serta memudahkan untuk merencanakan kerja selanjutnya berdasarkan apa yang telah dipahami.

Langkah penarikan kesimpulan dan verifikasi. Jika kesimpulan yang dibuat dirasakan masih memuat kejanggalan-kejanggalan, maka harus dilakukan verifikasi dengan sumber data. Untuk menganalisis data angket dan tes hasil belajar yang 
diberikan kepada peserta didik sebagai responden dalam penelitian ini, digunakan teknik persentase dengan rumus:

$$
P=\frac{f}{n} \times 100 \% \quad \text { (Sugiyono, 2010:43) }
$$

Dengan:

$$
\begin{aligned}
& \mathrm{P} \text { : angka persentase } \\
& \mathrm{f} \text { : banyaknya individu yang masuk kriteria } \\
& \mathrm{n}
\end{aligned}
$$

Sedangkan kategori penilaian terhadap hasil angket dan hasil tes sebagai berikut :

Tabel 1. Kategori penilaian

\begin{tabular}{cc}
\hline Rentang nilai & Kategori \\
\hline $84-100$ & Sangat baik \\
$67-83$ & Baik \\
$33-66$ & Cukup baik \\
$16-32$ & Kurang baik \\
$0-15$ & Tidak baik \\
\hline
\end{tabular}

\section{HASIL DAN PEMBAHASAN}

Penelitian dilakukan di SD Negeri 204 Palembang yang berlokasi di Jalan Mataram Kelurahan Kemas Rindo Kecamatan Kertapati. Keadaan lingkungan dengan halaman tertata rapi dan bersih membuat suasana proses belajar-mengajar menjadi nyaman.

Mata pelajaran matematika diajarkan di kelas $\mathrm{V}$ jumlah jam pelajaran 2 x 45 menit setiap minggu. Mata pelajaran Matematika di SD menggunakan kurikulum 2013 dengan Kompetensi Inti (KI) dan Kompetensi Dasar (KD) yang ditetapkan oleh pemerintah. Peserta didik yang mengikuti mata pelajaran matematika adalah kelas V yang terdiri 3 kelas dengan jumlah peserta didik sebanyak 74 orang. Dalam penyampaian materi matematika dilakukan tiga kali pertemuan dalam seminggu yaitu Senin, Selasa, dan Jum'at dua jam pelajaran (sumber: observasi lapangan, tanggal 19 Februari 2018).

Angket diberikan kepada peserta didik dalam bentuk pernyataan atau pertanyaan. Angket diberikan dalam bentuk kombinasi antara gambar dan tulisan agar mempermudah peserta didik dalam memahami dan mengisi angket. Berdasarkan data dari hasil jawaban angket peserta didik diperoleh hasil sebagai berikut:

Tabel 2. Rekapitulasi jawaban angket

\begin{tabular}{cccc}
\hline No. & $\begin{array}{c}\text { Kriteria tingkat kecerdasan } \\
\text { emosional }\end{array}$ & $\begin{array}{c}\text { Jumlah } \\
\text { peserta didik }\end{array}$ & Persentase \\
\hline 1 & Sangat baik & 12 & $16,2 \%$ \\
2 & Baik & 34 & $45,9 \%$ \\
3 & Cukup baik & 15 & $20,3 \%$ \\
4 & Kurang baik & 13 & $17,6 \%$ \\
5 & Tidak baik & 0 & $0 \%$ \\
\hline
\end{tabular}


Dari data di atas menunjukkan bahwa dari hasil angket, siswa yang memiliki kriteria sangat baik sebanyak 12 orang atau 16,2 \%, siswa yang memiliki kriteria baik sebanyak 34 orang atau 45,9\%, siswa yang memiliki kriteria cukup baik sebanyak 15 orang atau 20,3\%, siswa yang memiliki kriteria kurang baik sebanyak 13 orang atau $17,6 \%$, sedangkan tidak ada siswa yang memiliki kriteria tidak baik. Sehingga dapat disimpulkan bahwa sebagian besar siswa dikategorikan cukup baik kecerdasan emosionalnya.

Selanjutnya dari indikator dalam angket kecerdasan emosional diperoleh sebagai berikut:

Tabel 3. Data kecerdasan emosional peserta didik berdasarkan indikator

\begin{tabular}{llccccc}
\hline & $\begin{array}{c}\text { Kriteria } \\
\text { Ningkat } \\
\text { kecerdasan } \\
\text { emosional }\end{array}$ & $\begin{array}{c}\text { Mengenali } \\
\text { emosi diri } \\
\text { sendiri }\end{array}$ & $\begin{array}{c}\text { Mengelola } \\
\text { emosi }\end{array}$ & $\begin{array}{c}\text { Memotivasi } \\
\text { diri sendiri }\end{array}$ & $\begin{array}{c}\text { Mengenali } \\
\text { emosi orang } \\
\text { lain }\end{array}$ & $\begin{array}{c}\text { Membina } \\
\text { hubungan }\end{array}$ \\
\hline 1 & Sangat baik & - & - & - & - & - \\
2 & Baik & $71 \%$ & - & - & $68 \%$ & $70 \%$ \\
3 & Cukup baik & - & $65,1 \%$ & $64,9 \%$ & - & - \\
4 & Kurang baik & - & - & - & - & - \\
5 & Tidak baik & - & - & - & - & - \\
\hline
\end{tabular}

Tabel di atas menunjukkan data tiap aspek kecerdasan emosional peserta didik. Dapat diketahui bahwa aspek yang paling berpengaruh terhadap hasil belajar peserta didik adalah mengenali emosi diri sendiri (71\%), sedangkan aspek yang hasilnya paling rendah adalah memotivasi diri sendiri $(64,9 \%)$.

Setelah data hasil belajar matematika diperoleh melalui tes sebanyak 10 soal uraian, kemudian data diolah dan dianalisis untuk mengetahui hasil belajar matematika dalam menyelesaikan soal-soal matematika. Nilai yang diperoleh dapat dilihat pada tabel di bawah ini.

Tabel 4. Data hasil tes siswa kelas V SD Negeri 204 Palembang

\begin{tabular}{ccccc}
\hline No & $\begin{array}{c}\text { Kriteria tingkat hasil } \\
\text { belajar }\end{array}$ & Rentang nilai & $\begin{array}{c}\text { Jumlah peserta } \\
\text { didik }\end{array}$ & Persentase \\
\hline 1 & Sangat baik & $84-100$ & 12 & $16,2 \%$ \\
2 & Baik & $67-83$ & 36 & $48,6 \%$ \\
3 & Cukup baik & $33-66$ & 16 & $21,6 \%$ \\
4 & Kurang baik & $16-32$ & 5 & $6,8 \%$ \\
5 & Tidak baik & $0-15$ & 5 & $6,8 \%$ \\
\hline
\end{tabular}

Berdasarkan dari data di atas dapat diinformasikan mengenai nilai atau hasil tes peserta didik di SD Negeri 204 Palembang yaitu sebanyak 12 atau 16,2\% peserta didik yang dikatakan memiliki kriteria sangat baik, yang memiliki kriteria baik sebanyak 36 atau 48,6\% peserta didik, yang memiliki kriteria cukup baik sebanyak 16 atau 21,6\% peserta didik, yang memiliki kriteria kurang baik sebanyak 5 atau $6,8 \%$ peserta didik, sedangkan yang bernilai tidak baik sebanyak 5 atau $6,8 \%$ peserta 
didik. Dengan demikian berdasarkan hasil belajar peserta didik di SD Negeri 204 Palembang dapat dikatakan bahwa peserta didik mampu dalam menerima pembelajaran matematika.

Dari tabel di atas maka dapat dibuatlah Kriteria Ketuntasan Minimal (KKM) sebagai berikut:

Tabel 5. Kriteria ketuntasan minimal (KKM)

\begin{tabular}{ccccc}
\hline No & Nilai & $\begin{array}{c}\text { Jumlah peserta } \\
\text { didik }\end{array}$ & Persentase & Keterangan \\
\hline 1 & $>75$ & 48 & $64,9 \%$ & Tuntas \\
2 & $<75$ & 26 & $35,1 \%$ & Tidak Tuntas \\
\hline
\end{tabular}

Kemampuan peserta didik dalam menyelesaikan soal-soal matematika yaitu $64,9 \%$ yang tuntas dan 35,1\% yang tidak tuntas. Dari hasil ini menunjukkan bahwa kecerdsan emosional peserta didik mempengaruhi hasil belajar. Jika kecerdasan emosional peserta didik baik maka hasil belajar yang diperoleh tuntas, dan jika kecerdasan emosional peserta didik tidak baik maka hasil belajar yang diperoleh tidak tuntas.

Dari hasil angket menunjukkan bahwa terdapat 12 atau $16,2 \%$ peserta didik, yang memiliki tingkat kecerdasan emosional sangat baik, 34 atau 45,9\% peserta didik menunjukkan tingkat kecerdasan baik, sebanyak 15 atau 20,3\% peserta didik menunjukkan tingkat kecerdasan cukup baik, sebanyak 13 atau 17,6\% peserta didik menunjukkan tingkat kecerdasan kurang baik. Hasil belajar peserta didik menunjukkan terdapat 12 atau $16,2 \%$ peserta didik memiliki kiteria sangat baik, sebanyak 36 atau 48,6\% peserta didik memiliki kiteria baik sebanyak 16 atau 35\% peserta didik, memiliki kiteria cukup baik, sebanyak 5 atau 6,8\% peserta didik memiliki kiteria kurang baik, sedangkan sebanyak 5 atau $6,8 \%$ peserta didik memiliki kriteria tidak baik.

Berdasarkan hasil penelitian menunjukkan peserta didik yang memiliki tingkat kecerdasan emosional baik sebanyak 34 atau 45,9 \% peserta didik maka akan baik hasil belajar matematika yaitu sebanyak 36 atau 48,6\% peserta didik yang memiliki kriteria baik, sedangkan peserta didik yang memiliki kecerdasan emosional kurang baik maka hasil belajar kurang baik. Hal ini menunjukkan terdapat hubungan yang kuat antara kecerdasan emosional terhadap hasil belajar matematika peserta didik kelas V SD Negeri 204 Palembang,

Hasil belajar yang dimaksud di sini adalah hasil belajar kognitif peserta didik setelah proses pembelajaran. Hasil belajar peserta didik dipengaruhi oleh banyak faktor. Kecerdasan intelektual selama ini dianggap sebagai faktor utama yang mempengaruhi hasil belajar peserta didik. Peserta didik dengan kecerdasan intelektual tinggi dianggap lebih mudah dalam memahami materi yang diajarkan. Namun, pada kenyataannya masih banyak faktor lain yang turut mempengaruhi hasil belajar peserta didik, salah satunya adalah kecerdasan emosional.

Goleman (2016) menyatakan bahwa pendidikan yang disertai emosi cenderung lebih mudah dan kuat diingat. Prestasi dan keberhasilan peserta didik, dalam belajar tidak hanya ditentukan oleh kecerdasan intelektual melainkan juga ditentukan oleh keselarasan perkembangan antara kecerdasan intelektual dan kecerdasan emosional. 
Peserta didik dengan kecerdasan emosional yang tinggi cenderung berpikir dahulu sebelum mengambil suatu tindakan dan juga memahami benar-benar pertanyaan yang akan dijawab sehingga tidak mengalami kesulitan dalam mencari jawaban yang terdapat dalam dirinya sendiri dan dalam diri orang lain. Sementara peserta didik dengan kecerdasan emosional yang relatif rendah cenderung mengalami kesulitan dalam menemukan jawaban dalam dirinya sehingga ia juga kesulitan memahami pertanyaan yang akan dijawab dan mengakibatkan pertanyaan yang dijawab menjadi tidak tepat atau tidak yakin dengan apa yang dikerjakannya.

Kecerdasan emosional memegang peranan yang cukup signifikan dalam pencapaian hasil belajar peserta didik karena dapat meningkatkan kesadaran diri, sehingga peserta didik dapat lebih mudah untuk memusatkan perhatian dan lebih tekun dalam penyelesaian tugas. Kemampuan peserta didik dalam memahami kelemahan dan kelebihan yang ada pada dirinya berpengaruh terhadap hasil belajarnya. Peserta didik yang memahami kelemahannya dengan baik akan berusaha untuk memecahkan masalahnya secara mandiri atau dengan bantuan orang lain. Peserta didik dengan kecerdasan emosional tinggi mampu memanfaatkan waktu yang ada untuk menyelesaikan serangkaian tugas belajar dengan sebaik-baiknya.

Emosi berkaitan dengan perubahan fisiologis dan berbagai pikiran. Jadi, emosi merupakan salah satu aspek penting dalam kehidupan manusia, karena emosi dapat merupakan motivator perilaku dalam arti meningkatkan tapi juga dapat mengganggu perilaku intensional manusia (Prawitasari, 1998).

Selain itu, motivasi diri sendiri yang tinggi juga dibutuhkan peserta didik untuk berprestasi. Motivasi yang tinggi mampu membangkitkan semangat peserta didik untuk belajar. Untuk anak SD, guru mesti berperan aktif dalam memotivasi mereka. Kemampuan dalam memahami emosi orang lain dan keterampilan bersosialisasi juga diperlukan peserta didik untuk meningkatkan hasil belajarnya. Ketika peserta didik mampu membuat nyaman orang yang ada di dekatnya, maka dengan mudah peserta didik akan mengambil hatinya. Kemampuan tersebut sangat diperlukan ketika peserta didik membutuhkan bimbingan dari orang lain. Anak SD masih kurang mampu bergaul dengan orang-orang di sekitarnya, ketika menemui kesulitan belajar matematika, maka mereka kurang mampu untuk menyelesaikan masalahnya. Kecerdasan emosional juga sangat berhubungan dengan kemampuan komunikasi matematika baik tulis maupun lisan.

Senada dengan penelitian Maharani (2014) yang menyimpulkan bahwa anakanak yang dilatih emosinya sungguh-sungguh mampu mengontrol emosinya di kemudian hari. Untuk belajar matematika diperlukan pikiran yang tenang, santai tapi serius, dan bersemangat. Oleh karenanya peserta didik harus bisa menata emosinya agar selalu dalam keadaan stabil sehingga dapat mencapai hasil belajar yang optimal.

\section{SIMPULAN DAN SARAN}

Tingkat kecerdasan emosional siswa diperoleh dengan kriteria sangat baik 12 peserta didik $(16,2 \%)$, kriteria baik 34 peserta didik (45,9\%), cukup baik 15 peserta didik (20,3\%), dan kurang baik 13 peserta didik (17,6\%). Hasil belajar peserta didik diperoleh dengan kriteria sangat baik ada 12 peserta didik $(16,2 \%)$, kriteria baik ada 36 peserta didik (48,6\%), cukup baik 16 peserta didik (35\%), kurang baik 5 peserta didik $(6,8 \%)$ dan tidak baik 5 peserta didik $(6,8 \%)$. Maka ada hubungan yang positif antara kecerdasan emosional dengan hasil belajar kelas V SD Negeri 204 Palembang. 
Pihak Sekolah diharapkan agar dapat menyelaraskan proses belajar-mengajar yang tidak hanya menjunjung dan membekali peserta didik dengan kecerdasan intelektual semata (cognitif aspect) namun dapat memikirkan aspek kecerdasan emosional peserta didik. Bagi guru, diharapkan harus mempertahankan dan meningkatkan pembinaan terhadap penanaman nilai-nilai dan karakter peserta didik. Penanaman nilai-nilai spiritual akan mendukung kematangan kecerdasan emosional peserta didik.

\section{DAFTAR PUSTAKA}

Agustian, A. G. 2007. Rahasia Sukses Membangun Kecerdasan Emosi dan Spiritual ESQ: Emotional Spiritual Quotient Berdasarkan 6 Rukun Iman dan 5 Rukun Islam. Jakarta: ARGA Publishing.

Fuad, M. 2004. Survei Diagnosis Organisasional. Semarang: Universitas Diponegoro.

Goleman, D. 2016. Emotional Intelligence : Diterjemahkan oleh Sukoco. Jakarta: PT. Gramedia Pustaka Utama.

Ilyas, M. 2014. Pembelajaran Matematika Berbasis Karakter dengan Melibatkan Kecerdasan Emosional Mahasiswa. Makalah Pada Prosiding Seminar Nasional Pendidikan Karakter Universitas Cokroaminoto Palopo, Palopo, 3 Mei 2014. Vol. 1(1) : 47-54.

Maharani, A. 2014. Mengenal Kecerdasan Emosional dalam Pembelajaran Matematika. DELTA : Jurnal Ilmiah Pendidikan Matematika, Vol. 2(1) : 6370.

Nasution. 1995. Berbagai Pendekatan dalam Proses Belajar Mengajar. Jakarta: Bumi Aksara.

Prawitasari, J.E. 1998. Kecerdasan Emosi. Buletin Psikologi, Vol 6(1) : 21-31.

Slameto. 2016. Belajar dan Faktor-faktor yang Mempengaruhinya. Jakarta: Rineka Cipta.

Sugiyono. 2008. Memahami Penelitian Kualitatif. Bandung: Alfabeta.

Sugiyono. 2010. Metode Penelitian Kuantitatif, Kuanlitatif dan R\&D. Bandung: Alfabeta.

Sugiyono. 2014. Metode Penelitian Kuantitatif, Kuanlitatif dan R\&D. Bandung: Alfabeta.

Uno, H.B. 2008. Model Pembelajaran. Jakarta: Bumi Aksara.

Yusuf, S. 2002. Pengantar Psikologi. Bandung: Universitas Pendidikan Indonesia. 